\title{
Polysaccharides of red alga Gracilaria intermedia: structure, antioxidant activity and rheological behavior
}

\author{
Joana Paula Lima de Castro', Luís Eduardo Castanheira Costa', Maísa Pessoa Pinheiro', \\ Thiago dos Santos Francisco², Pedro Hermano Menezes de Vasconcelos ${ }^{3}$, Lizandra Mistrello Funari 4 , \\ Renata Moschini Daudt ${ }^{4}$, Gustavo Ramalho Cardoso dos Santos ${ }^{5}$, Nilo Sérgio Medeiros Cardozo ${ }^{4 *}$ \\ and Ana Lúcia Ponte Freitas
}

\author{
'Departmento de Bioquímica e Biologia Molecular, Universidade Federal do Ceará - UFC, \\ Fortaleza, CE, Brazil \\ ${ }^{2}$ Departmento de Química Orgânica e Inorgânica, Universidade Federal do Ceará - UFC, \\ Fortaleza, CE, Brazil \\ ${ }^{3}$ Departmento de Química, Instituto Federal de Educação, Ciência e Tecnologia do Ceará, \\ Fortaleza, CE, Brazil \\ ${ }^{4}$ Departmento de Engenharia Química, Universidade Federal do Rio Grande do Sul - UFRGS, \\ Porto Alegre, $R S$, Brazil \\ ${ }^{5}$ Laboratório de Tecido Conjuntivo, Universidade Federal do Rio de Janeiro - UFRJ, \\ Rio de Janeiro, RJ, Brazil \\ *nilo@enq.ufrgs.br
}

\begin{abstract}
A sulfated polysaccharide fraction from the red alga Gracilaria intermedia (PLS) was obtained by papain digestion $\left(60^{\circ} \mathrm{C}, 30 \mathrm{~min}\right)$. The extract was subjected to colorimetry and turbidimetry analysis, Fourier transform infrared (FTIR) spectroscopy, ${ }^{1} \mathrm{H},{ }^{13} \mathrm{C}$ and ${ }^{2} \mathrm{D}{ }^{1} \mathrm{H}$ COSY nuclear magnetic resonance (NMR) and gas chromatography/mass spectrometry analysis. Antioxidant activity tests were performed (chelation of ferrous ion, total antioxidant capacity, and scavenging of DPPH radicals); significant activity of the extract indicated that these polysaccharides may be used as non-synthetic antioxidants. The rheological behavior of aqueous polysaccharide solutions was studied at $25 \pm 1{ }^{\circ} \mathrm{C}$ using steady-shear and dynamic oscillatory measurements. All the solutions analyzed showed pseudoplastic behavior and potential to act as a thickening agent, as proved through a preliminary comparison with a commercial product used for this application.
\end{abstract}

Keywords: antioxidant activities, Gracilaria intermedia, polysaccharides, rheological behavior, structure.

\section{Introduction}

Polysaccharides are polymers that show a wide range of properties depending on their monomeric composition and have applications in different types of industries. Applications include the use as a stabilizer, thickener, flocculant, and water-retaining agent in the textile, food, pharmaceutical, and biotechnology industries ${ }^{[1-4]}$.

Carrageenans and agarans are sulfated polysaccharides obtained from red algae. The industrial applications of these polymers are closely dependent on their rheological properties. Such properties make these two polymers important gelling agents and thickeners, especially in the food industry ${ }^{[5]}$. Sulfated polysaccharides also exhibit various biological activities, including antioxidant activities, among others $^{[6-9]}$. Therefore, they also have potential application as agents to reduce cellular damage and to prolong the shelf time of foods; these are areas where compounds with antioxidant activity are currently in great demand ${ }^{[10-12]}$. Non-synthetic compounds, particularly polysaccharides, with antioxidant potential are currently under investigation by several research group ${ }^{[13-18]}$ as an alternative to synthetic antioxidant compounds traditionally used in the food and pharmaceutical industries such as butylated hydroxytoluene
(BHT), butylated hydroxyanisole (BHA), and tert-butyl hydroquinone (TBHQ) due to their suspected damage to liver tissue and carcinogenic potential[ ${ }^{[9,13,19]}$.

Red algae from the genus Gracilaria are economically important in the phycocolloids industry ${ }^{[20]}$ and are currently the source of about $65 \%$ of the 7.5 tons of agar produced annually throughout the world ${ }^{[21]}$. Sulfated polysaccharides obtained from species of the genus Gracilaria contain 3-linked- $\beta$-D-galactopyranose ( $\mathrm{G}$ unit) and 4-linked3,6 -anhydro- $\alpha$-L-galactopyranose (LA unit) ${ }^{[22-25]}$ with substitution of hydroxyl groups by ester sulfate, methyl groups, and pyruvic acid ${ }^{[23-26]}$ (Figure 1). Gracilaria is very common in the Northeast Brazilian coast and its extraction has been pointed as an alternative for the economic inclusion of part of the population of this region ${ }^{[27]}$.

Yield of extraction and final properties of agarans depend strongly on the seaweed species, the methodology of extraction of polysaccharides, seasonal variations and the place of origin of the specimens. So the chemical, structural, and rheological characterization of polysaccharydes extracted from seaweeds is necessary ${ }^{[26,28]}$. In the specific case of the 

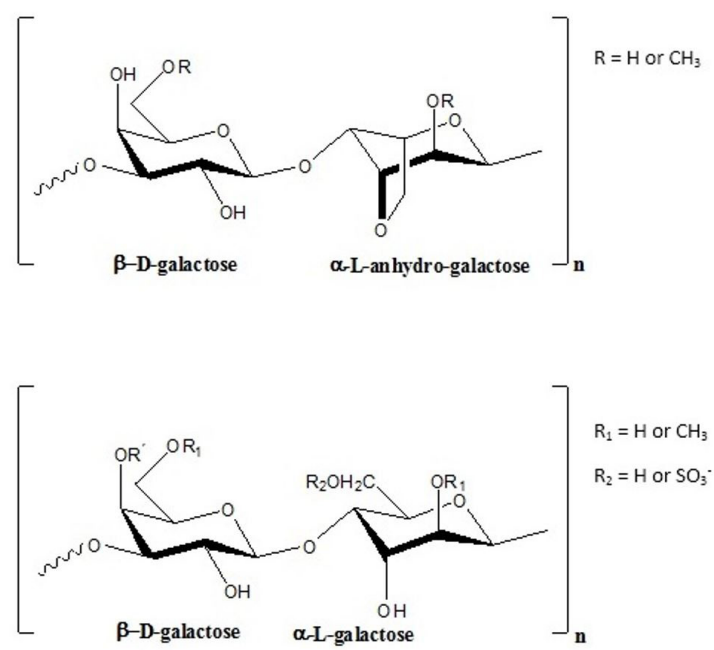

Figure 1. Chemical structure of agar type molecules with the different types of sugar units and substituents.

species Gracilaria intermedia, the related scientific research Gracilaria intermedia is still scarce. To the knowledge of the authors, only studies on its taxonomy ${ }^{[28-31]}$ and ecological aspects $^{[32]}$ have been reported.

In this context, the goal of this paper was to characterize sulfated polysaccharides extracted from the red seaweed Gracilaria intermedia. This characterization was performed by spectroscopy, turbidimetric and colorimetric methods. The antioxidant activity of the polymer and its rheological behavior in solution were also evaluated.

\section{Materials and Methods}

\subsection{Materials}

Papain, cysteine and cetylpyridinium chloride (CPC) were obtained from Vetec (Brazil), ammonium molybdate was purchased from Dinâmica (Brazil) and D-galactose from Acros Organics (USA). Ferrozine, 1, 1-diphenyl2-picrylhydrazyl (DPPH) and bovine serum albumin (BSA) were purchased from Sigma-Aldrich (USA). Ascorbic acid was obtained from Synth (Brazil) and Carboxymethyl cellulose was obtained from Mix (Brazil). All other solvents and chemicals were of analytical grade.

\subsection{Extraction of sulfate polysaccharides}

Specimens of $G$. intermedia were collected in April 2013 on the Atlantic coast of Brazil (Taiba beach, São Gonçalo - Ceará). The collected seaweed were cleaned of epiphytes, washed with distilled water, and stored at $-20{ }^{\circ} \mathrm{C}$. A voucher specimen $\left(\mathrm{n}^{\circ} 2386\right)$ was deposited in the phycological Herbarium of the Laboratory of Marine Sciences, Universidade Federal do Ceará, Brazil.

The enzymatic extraction of polysaccharides was performed according to the methodology of Farias et al. ${ }^{[33]}$, with some modifications. The dried tissue $(5 \mathrm{~g})$ was suspended in $250 \mathrm{~mL}$ of 0.1 mol.L $\mathrm{L}^{-1}$ sodium acetate buffer ( $\mathrm{pH} 5.0$ ), containing $1 \mathrm{~g}$ of papain, $5 \times 10^{-3} \mathrm{~mol} . \mathrm{L}^{-1}$ EDTA, and $5 \times 10^{-3}$ mol.L $\mathrm{L}^{-1}$ cysteine, and incubated at $60{ }^{\circ} \mathrm{C}$ for $30 \mathrm{~min}$. The incubation solution was then filtered through a nylon membrane, and the homogenate was retained. The polysaccharides in solution were precipitated with $16 \mathrm{~mL}$ of $10 \%$ cetylpyridinium chloride (CPC) solution. After $24 \mathrm{~h}$ at room temperature $\left(25^{\circ} \mathrm{C}\right)$, the mixture was centrifuged at $2,560 \times \mathrm{g}$ for $20 \mathrm{~min}$ at $20^{\circ} \mathrm{C}$. The polysaccharides were washed with $500 \mathrm{~mL}$ of $0.05 \%$ CPC solution, dissolved with $100 \mathrm{~mL}$ of a 2 mol.L $\mathrm{L}^{-1}$ $\mathrm{NaCl}$-ethanol $(100: 15, \mathrm{v} / \mathrm{v})$ mixture, and the excess of salts was removed by precipitation and wash with $200 \mathrm{~mL}$ of absolute ethanol. After $24 \mathrm{~h}$ at $4{ }^{\circ} \mathrm{C}$, the precipitate was collected by centrifugation $\left(2,560 \times \mathrm{g}\right.$ for $20 \mathrm{~min}$ at $\left.20^{\circ} \mathrm{C}\right)$, washed extensively with ethanol- $80 \%$, then absolute ethanol. After this, the polysaccharides (PLS) were washed with acetone, which was followed by hot air drying $\left(60^{\circ} \mathrm{C}\right)$ until all the acetone was removed.

\subsection{Chemical analysis}

Sulfate content of PLS was determined by the barium-gelatin method $^{[34]}$ after hydrolysis of the sample in 1 mol.L $\mathrm{L}^{-1} \mathrm{HCl}$ $\left(5 \mathrm{~h}, 105^{\circ} \mathrm{C}\right)$ using sodium sulfate $\left(\mathrm{Na}_{2} \mathrm{SO}_{4}\right)$ as standard. To measure the amount of total neutral carbohydrates the phenol-sulfuric method was performed ${ }^{[35]}$ with a standard curve prepared with D-galactose. The protein content was measured by the Bradford method ${ }^{[36]}$ using bovine serum albumin (BSA) as standard.

\subsection{Monosaccharide composition}

Samples of the polysaccharides extracted from $G$. intermedia (5 mg) were hydrolyzed with 5 mol.L $\mathrm{L}^{-1}$ trifluoroacetic acid for $4 \mathrm{~h}$ at $100^{\circ} \mathrm{C}$, reduced with borohydride, and the alditols were acetylated with acetic anhydride:pyridine $(1: 1, \mathrm{v} / \mathrm{v})$. The alditols acetates were dissolved in chloroform and analyzed in a gas-liquid chromatograph/mass spectrometrer (GCMS-QP2010 Shimadzu, Japan) with a DB-5ms column (Agilent) ${ }^{[37]}$.

\subsection{Infrared spectroscopy}

The Fourier transform infrared spectra (FTIR) were obtained with a Shimadzu IR spectrophotomer (FTLA 2000, ABB-BOMEM, Canada) with measurements in the wavenumber range of $400-4000 \mathrm{~cm}^{-1}$ using 20 scans. The samples were analyzed as $\mathrm{KBr}$ pellets.

\subsection{Nuclear magnetic resonance (NMR) spectroscopy}

The spectroscopic technique of nuclear magnetic resonance (NMR) is a method commonly used for structural characterization of seaweed polysaccharides ${ }^{[38-41]}$.

${ }^{1} \mathrm{H},{ }^{13} \mathrm{C}$ and $2 \mathrm{D}{ }^{1} \mathrm{H}$ COSY NMR spectra in $\mathrm{D}_{2} \mathrm{O}$ were recorded at $353 \mathrm{~K}$ on a Fourier transform spectrometer (Bruker Avance DRX 500, USA) with an inverse multinuclear gradient probe-head equipped with z-shielded gradient coils.

\subsection{Determination of antioxidant activity}

\subsubsection{Total antioxidant capacity}

The total antioxidant capacity test, based on the reduction of $\mathrm{Mo}^{6+}$ to $\mathrm{Mo}^{5+}$, was performed by the methodology proposed by Prieto, Pineda \& Aguilar ${ }^{[42]}$. Aliquots of the polysaccharide solution $(0.1 \mathrm{~mL})$ of different concentrations $(0.1 \%$ to $1.5 \%)$ were mixed with $1 \mathrm{~mL}$ of the reagent solution (0.6 mol.L $\mathrm{L}^{-1}$ sulfuric acid, $28 \times 10^{-3} \mathrm{~mol} . \mathrm{L}^{-1}$ sodium phosphate, 
and $4 \times 10^{-3}$ mol.L $\mathrm{L}^{-1}$ ammonium molybdate). This step was followed by incubation at $95^{\circ} \mathrm{C}$ for $90 \mathrm{~min}$. Subsequently, absorbance was read at $695 \mathrm{~nm}$. A standard curve under the same conditions was prepared with solutions of ascorbic acid. Thus, the results are presented as equivalence of ascorbic acid (mg/g EAAsc).

\subsubsection{Iron ( $\mathrm{Fe}^{2+}$ ) chelating activity}

The iron ion is associated with lipid peroxidation due to the Fenton reaction. This process is related to a series of diseases ${ }^{[43-45]}$. The antioxidants form a complex with this ion, thus preventing cell damage ${ }^{[46]}$. The ferrous ion chelation activity of PLS was investigated according to the methodology used by Zhang et al. ${ }^{[18]}$. Aliquots of $1 \mathrm{~mL}$ of the polysaccharide solution at different concentrations $(0.1 \%$ to $1.5 \%)$ were mixed with $0.05 \mathrm{~mL}$ of $\mathrm{FeCl}_{2}\left(2 \times 10^{-3}\right.$ mol.L $\left.\mathrm{L}^{-1}\right)$, $0.2 \mathrm{~mL}$ of ferrozine $\left(5 \times 10^{-3} \mathrm{~mol} \cdot \mathrm{L}^{-1}\right)$, and $2.75 \mathrm{~mL}$ of water. The solution was agitated and incubated at room temperature for $10 \mathrm{~min}$. Absorbance of the solution at $562 \mathrm{~nm}$ was measured. The chelating activity was calculated using the following Equation 1:

$$
\text { Chelating activity }(\%)=\left[1-\frac{A_{1}-A_{2}}{A_{0}}\right] \times 100
$$

where $\mathrm{A}_{0}$ is the absorbance of the blank, $\mathrm{A}_{1}$ is the absorbance of the test solution, and $A_{2}$ is the absorbance of a solution identical to $\mathrm{A}_{1}$ with the substitution of $\mathrm{FeCl}_{2}$ for the same aliquot of water. Ascorbic acid was used as the positive control.

\subsubsection{Scavenging of DPPH radicals}

The 1,1-diphenyl-2-picrylhydrazyl free radical (DPPH) scavenging activity of PLS was measured using the method used by $\mathrm{Wu}$ et al. ${ }^{[16]}$. Ascorbic acid was used as a positive control. The inhibition (\%) was calculated using the following Equation 2:

$$
\text { Scavenging of DPPH radicals }(\%)=\frac{\left(A_{0}-A_{1}\right)}{A_{0}} \times 100
$$

where $\mathrm{A}_{0}$ and $\mathrm{A}_{1}$ are the absorbance of the blank and sample, respectively.

\subsection{Rheological behavior}

Rheological measurements were carried out in a rotational rheometer (Ares, TA Instruments, New Castle, DE, USA), using cone-plate geometry (50 $\mathrm{mm}$ diameter, cone angle of $0.0399 \mathrm{rad}$, gap of $0.0553 \mathrm{~mm}$ ). All measurements were run at $25 \pm 1{ }^{\circ} \mathrm{C}$.

Dynamic tests were performed to evaluate the behavior of storage (G') and loss (G') moduli as a function of frequency. The frequency sweep tests were performed in the linear viscoelastic region (LVR), determined through strain sweep tests. Three samples containing the extracted sulfated PLS $(1.0 \%, 1.25 \%$, and $1.5 \%)$ were analyzed.

Flow curves were obtained by recording shear stress values when shearing the samples at an increasing shear rate from 0.1 to $100 \mathrm{~s}^{-1}$ with increment of $4 \mathrm{~s}^{-1}$ and then reducing it through the same path. This test was performed for samples containing PLS in different concentrations $(1.0 \%, 1.25 \%$, and $1.5 \%)$. Additionally, for testing the potential of PLS as thickening agent, solutions containing carboxymethylcellulose (CMC), a well-known thickening agent, and blends of CMC and PLS were also analyzed. The concentrations of the referred CMC solutions were of $0.75 \%$ of CMC and $1.5 \%$. In the case of the blends, two formulations were prepared, one containing $1.0 \%$ of PLS and $0.5 \%$ of CMC and another containing $0.75 \%$ of PLS and $0.75 \%$ of CMC.

The data of the flow curves were fitted using the Ostwald-de Waele model (power-law), Equation 3:

$$
\eta=K \dot{\gamma}^{n-1}
$$

where: is the shear viscosity $(\mathrm{Pa} \cdot \mathrm{s}), K$ is the consistency index (Pa.s); is the shear rate $\left(\mathrm{s}^{-1}\right), n$ is the power-law index (dimensionless) and $K$ is the consistency index (Pa.s). The estimation of the parameters $\mathrm{K}$ and $\mathrm{n}$ was performed using the least-square method, in the software Microsoft Excel.

\section{Results and Discussions}

\subsection{Yield and chemical analysis}

The yield of polysaccharides by mass of seaweed Gracilaria intermedia was $17.0 \pm 1.18 \%$. Studies which extraction took place by enzymatic digestion of seaweed Gracilaria cornea (Brazil) achieved yields of $18.0 \%{ }^{[28]}$ and 11.0 to $21.4 \%{ }^{[47]}$. Souza et al. ${ }^{[12]}$ in Brazil obtained a polysaccharide yield of $27.2 \%$ for the seaweed Gracilaria birdeae while Freile-Pelegrin and Robledo ${ }^{[48]}$, on a seasonal study in Mexico, obtained yield from 25.0 to $39.3 \%$ for Gracilaria cervicornis. In extraction performed at room temperature, in Brazil, Maciel et al. ${ }^{[23]}$ were able to yield $6.5 \%$ of polysaccharides from seaweed Gracilaria birdeae. Making the extraction of polysaccharides with autoclave in India, yields of 14.8\% for Gracilaria debilis and 15.2\% for Gracilaria Salicornia ${ }^{[49]}$ were achieved.

Polysaccharides from Gracilaria intermedia (PLS) exhibited $6.60 \pm 0.13 \%$ of sulfate, which is within the range of sulfate polysaccharides content from the other Gracilaria species $(2.30-8.90 \%)^{[23]}$. More recent studies indicate that this interval is actually wider, since percentages of sulphate of $0.76 \pm 0.08 \%$ (Gracilaria debilis, India $)^{[49]}$, $1.00 \pm 0.05 \%$ (Gracilaria caudata, Brazil ${ }^{[26]}$, and $15.66 \%$ (Gracilaria cornea, Brazil) ${ }^{[28]}$ have already been reported.

The carbohydrate content was $54.64 \pm 1.19 \%$, consistent with the percentage value of D - galactose found in other Gracilaria species. Amorin et al. ${ }^{[50]}$ performed the test sulfuric phenol in different fractions of Gracilaria ornata, Brazil, and found levels of sugars ranging between 33.14 and $62.20 \%$. In polysaccharide fractions of seaweed Gracilaria birdeae, Brazil, sugar content between 30.8 and $68.2 \%{ }^{[51]}$ were found.

Proteins were not detected in the polysaccharide fraction obtained from seaweed Gracilaria intermedia.

\subsection{Monosaccharide composition}

The monosaccharide composition of the polysaccharide extracted from G.intermedia was determined based on gas chromatography/mass spectrometry analysis of the alditol acetates formed after acid hydrolysis. The major monosaccharide detected was galactose. This finding is in agreement with results presented by Pomin \& Mourão ${ }^{[52]}$ 
who describe the presence of sulfated galactans in red algae. No other sugar was detected up to a limit of $<2 \%$ as $\%$ of dry weight, ensuring the purity of the material.

\subsection{Infrared spectroscopy}

Figure 2 shows the FTIR spectrum of the extracted polysaccharide fraction, expanded in the region between 1400 and $700 \mathrm{~cm}^{-1}$ to better identify the sulfate groups bands. The bands found at 1375 and $1258 \mathrm{~cm}^{-1}$ may be attributed to sulfate ester groups ${ }^{[51,52]}$, the band at $1075 \mathrm{~cm}^{-1}$ corresponds to galactan ${ }^{[53,54]}$, and the band at $892 \mathrm{~cm}^{-1}$ corresponds to the agar-specific band ${ }^{[55]}$. The band at $931 \mathrm{~cm}^{-1}$ corresponds to the C-O-O group present in the 3,6 -anhydrogalactose, and the bands between 820 and $860 \mathrm{~cm}^{-1}$ indicate the presence of sulfate groups ${ }^{[33-57]}$.

\subsection{NMR spectroscopy}

Figures 3 and 4 show, respectively, the $1 \mathrm{D}\left({ }^{1} \mathrm{H}\right.$ and $\left.{ }^{13} \mathrm{C}\right)$ and 2D NMR spectra of the polysaccharide fraction extracted from G.intermedia. The ${ }^{1} \mathrm{H}$ NMR spectrum is somewhat complex due to overlap and enlargement of the signs (Figure 3a). It shows the signals from the $\alpha$-anomeric proton at $\delta 5.62,5.14$ and 4.69 (assigned, respectively, to 3,6- $\alpha-\mathrm{L}-$ anhydrogalactose linked to $\beta$-D-galactose, $\alpha$-L-galactose6 -sulfate linked to $\beta$-D-galactose and $\beta$-D-galactose linked to 3,6- $\alpha$-L-anhydrogalactose), and from the H-1 of $\beta$-D-galactose linked to 3,6- $\alpha$-L-anhydrogalactose with a signal at $\delta 4.69^{[23,26,38-41,58]}$. However, the $\mathrm{H}-1 \beta$-D-galactose linked to $\alpha$-L-galactose-6-sulfate was not detected, probably due to the signal overlap. Others studies state that when this unit is linked with $\alpha-3,6$-anhydrogalactose and L- $\alpha$-Lgalactose-6-sulfate, there are minor chemical variations in the region of 4.65-3.90 ppm. Therefore, its identification is difficult ${ }^{[23,26,58,59]}$.

The anomeric region of ${ }^{13} \mathrm{C}$ NMR (90-110 ppm) shows four main signals (Figure 3b), which were assigned based on the literature data ${ }^{[23,26,38-41,58,60,61]}$, just like the other carbons observed in the region of 59-85 ppm (Table 1). The C-1 of $\beta$-D-galactose linked to $\alpha$-L-galactose-6-sulfato at $\delta 103.7$; C-1 of $\beta$-D-galactose linked to $3,6-\alpha$-L-anhydrogalactose at $\delta$ $102.5 ; \mathrm{C}-1$ of $\alpha$-L-galactose-6-sulfato linked to $\beta$-D-galactose at $\delta 101.25$ and $\mathrm{C}-1$ of 3,6- $\alpha$-L-anhydrogalactose linked to $\beta$-D-galactose at $\delta$ 98.4.

2D COSY was used to determine the proton resonance sequence (Figure 4). Regarding the dimer formed by 3,6- $\alpha$-L-anhydrogalactose linked to $\beta$-D-galactose five couplings relating the 3,6- $\alpha-\mathrm{L}$-anhydrogalactose $u$ and two couplings assigned $\beta$-D-galactose are observed. The protons that are coupled are H-1 (3,6- $\alpha$-L-anhydrogalactose)/H-2 $(3,6-\alpha-\mathrm{L}$-anhydrogalactose $)$ at $\delta 5.62 / 4.60 ; \mathrm{H}-2$ (3,6- $\alpha$-L-anhydrogalactose)/H-3 (3,6- $\alpha$-L-anhydrogalactose) at $\delta 4.60 / 5.04 ; \mathrm{H}-3(3,6-\alpha$-L-anhydrogalactose $) / \mathrm{H}-4$ $(3,6-\alpha-\mathrm{L}$-anhydrogalactose $)$ at $\delta 5.04 / 4.11 ; \mathrm{H}-4$ (3,6- $\alpha$-L-anhydrogalactose)/H-5 (3,6- $\alpha$-L-anhydrogalactose) at $\delta 4.11 / 4.26 ; \mathrm{H}-1$ ( $\beta$-D-galactose)/H-2 ( $\beta$-D-galactose) at $\delta 4.69 / 4.44$ and $\mathrm{H}-2$ ( $\beta$-D-galactose)/H-3 ( $\beta$-D-galactose) at $\delta 4.44 / 3.91$. For the $\alpha$-L-galactose- 6 -sulfate dimer linked to $\beta$-D-galactose a coupling is observed for the $\mathrm{H}-1$ ( $\alpha$-L-galactose-6-sulfato)/H-2 ( $\alpha$-L-galactose-6-sulfato) at $\delta 5.14 / 5.05$. Although other engagements can be observed,

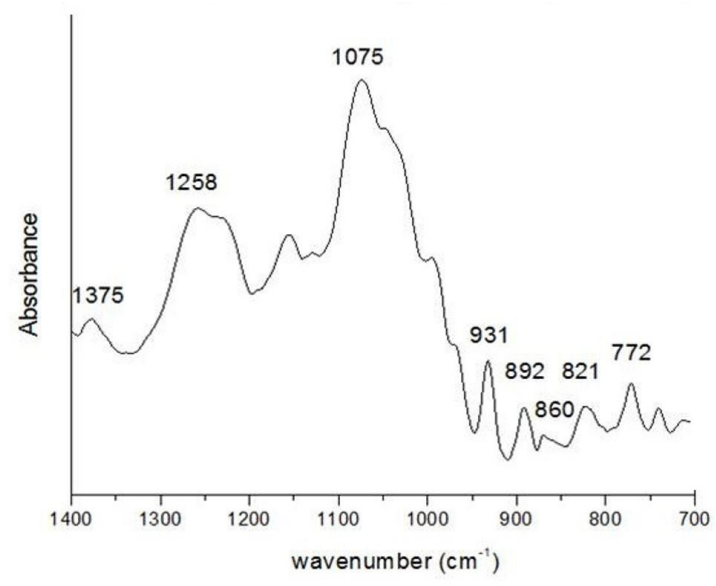

Figure 2. The IR spectra of the PLSs were determined using a Fourier transform infrared spectrometer (FTIR).

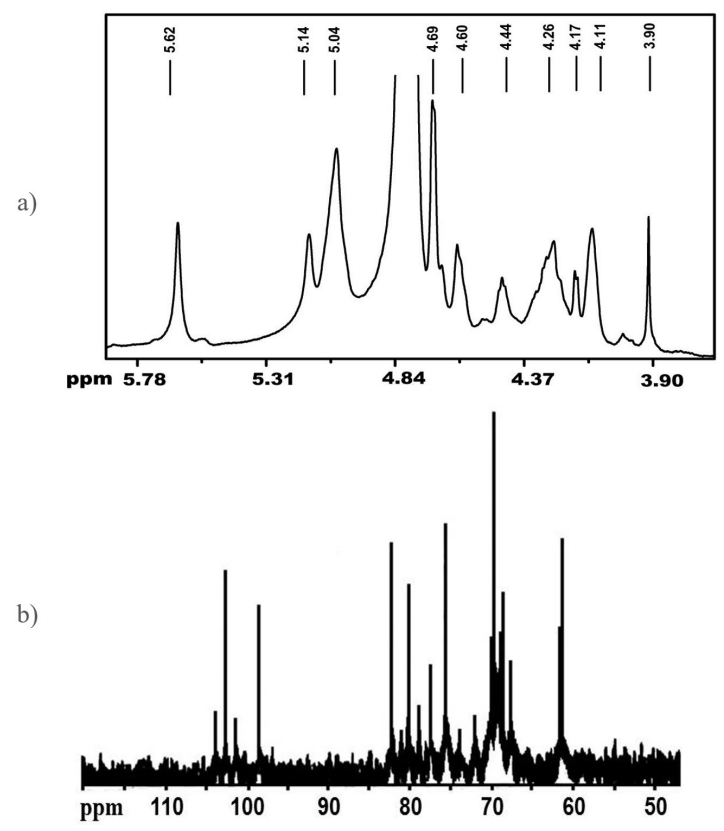

Figure 3. ${ }^{1} \mathrm{HNMR}$ (a) and ${ }^{13} \mathrm{CNMR}$ (b) spectra of the PLSs extracted from Gracilaria intermedia in $\mathrm{D}_{2} \mathrm{O}$ solution.

it is not possible to identify the sequence of hydrogens because the one-dimensional ${ }^{1} \mathrm{H}$ spectrum overlap them.

\subsection{Determination of antioxidant activity}

The total antioxidant capacity was determined by forming a phosphomolybdenum complex when $\mathrm{Mo}^{6+}$ is reduced to $\mathrm{Mo}^{5+}$; PLS showed activity with $28.98 \pm 1.86 \mathrm{mg} / \mathrm{g}$ EAAsc. In studies performed by Costa et al ${ }^{[62]}$ the amount of ascorbic acid in the seaweeds Codium isthmocladum and Spatoglossum schroederi were $(9.2 \mathrm{mg} / \mathrm{g}$ EAAsc) and $(14.4 \mathrm{mg} / \mathrm{g}$ EAAsc $)$ respectively. These values are inferior amount to the ones exhibited by the polysaccharides extracted from $G$. intermedia.

The ability of the PLS to chelate iron (II) ions was dose-dependent. Even though PLS led to higher chelation percentage than the ones obtained from ascorbic acid 
Table 1. ${ }^{1} \mathrm{H}$ and ${ }^{13} \mathrm{C}$ NMR chemical shifts for residues of $\mathrm{G}$. intermedia polysaccharide.

\begin{tabular}{|c|c|c|c|c|c|c|}
\hline \multirow[t]{2}{*}{ Residue } & \multicolumn{6}{|c|}{${ }^{1} \mathrm{H}$ chemical shift (ppm) } \\
\hline & H-1 & H-2 & H-3 & H-4 & H-5 & H-6 \\
\hline $3,6-\alpha$-L-anhydrogalactose linked to $\beta$-D-galactose & 5.62 & 4.60 & 5.04 & 4.11 & 4.26 & nd* \\
\hline$\beta$-D-galactose linked to $3,6-\alpha$-L-anydrogalactose & 4.69 & 4.44 & 3.91 & $\mathrm{nd}^{*}$ & nd* & nd* \\
\hline \multirow[t]{3}{*}{$\alpha$-L-galactose- 6 -sulfato linked to $\beta$-D-galactose } & 5.14 & 5.05 & $\mathrm{nd}^{*}$ & $\mathrm{nd}^{*}$ & nd* & $\mathrm{nd}^{*}$ \\
\hline & \multicolumn{6}{|c|}{${ }^{13} \mathrm{C}$ chemical shift (ppm) } \\
\hline & C-1 & C-2 & C-3 & C-4 & C-5 & C-6 \\
\hline $3,6-\alpha$-L-anhydrogalactose linked to $\beta$-D-galactose & 98.4 & $\mathrm{nd}^{*}$ & 81.2 & 77.5 & nd* & 69.5 \\
\hline$\beta$-D-galactose linked to $3,6-\alpha$-L-anhydrogalactose & 102.5 & nd* & 82.1 & 68.7 & 73.8 & 61.5 \\
\hline$\alpha$-L-galactose linked to $\beta$-D-galactose & 101.25 & nd* & nd* & 78.75 & 71.9 & 67.5 \\
\hline$\beta$-D-galactose linked to $\alpha$-L-galactose- 6 -sulfato & 103.7 & 70.5 & 80.2 & 69.3 & 75.6 & 61.8 \\
\hline
\end{tabular}

nd, not detected; *Signal which can be overlapped with the signal of similar units.

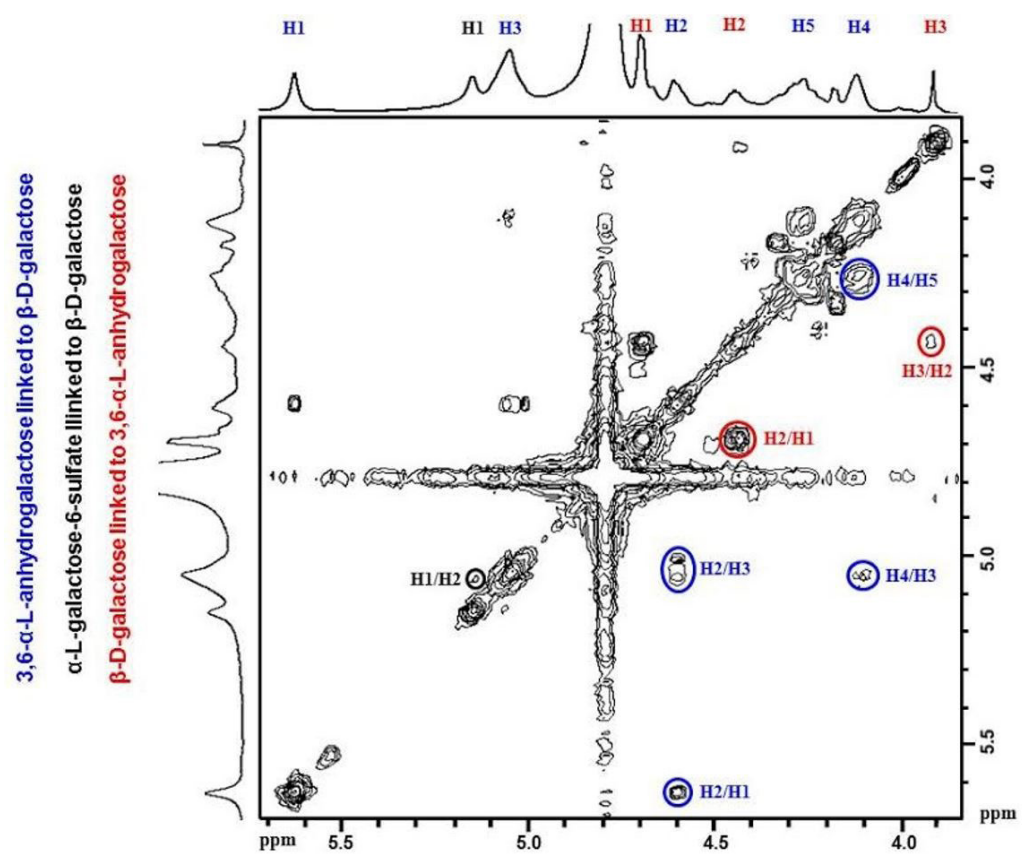

Figure 4. 2D COSY spectrum of PLSs from Gracilaria intermedia in $\mathrm{D}_{2} \mathrm{O}$.

(Figure 5a), its activity is low if compared to other polysaccharides extracted from seaweeds. The values for PLS were $11.64 \pm 0.83 \%$ (PLS $0.1 \%$ ) and $2819 \pm 0.97 \%$ (PLS $1.5 \%$ ). Costa et al. ${ }^{[62]}$ found a value of $40.2 \%$ of iron (III) chelation in solutions of $1.5 \mathrm{mg} \cdot \mathrm{mL}^{-1}$ of polysaccharides from Gracilaria caudata. Wang et al. ${ }^{[63]}$ studied different polysaccharide fractions from Laminaria japonica and found a value of $29.48 \%$ for quelation in a $1.17 \mathrm{mg}$. $\mathrm{mL}^{-1}$ solution.

The DPPH radical scavenging capacity of PLS was also dose-dependent, with a blockage varying from $9.89 \pm 1.32 \%$ (at a concentration of $0.1 \%$ ) to $41.83 \pm 0.97 \%$ (at a concentration of $1.5 \%$ ). Although significant, the DPPH radical scavenging capacity of PLS was lower than that ascorbic acid over the concentration range tested (Figure $5 \mathrm{~b}$ ) and also lower than the activity of other polysaccharides from seaweeds. Dore et al. ${ }^{[14]}$, with polysaccharides from Sargassum vulgare, found values of $10.0 \pm 0.7 \%$ a $22.0 \pm 0.6 \%$ in solutions that varied from 0.15 to $3.0 \mathrm{mg} \cdot \mathrm{mL}^{-1}$

\subsection{Rheological characterization}

Based on the strain sweep tests performed to determine the region linear viscoelastic behavior of the samples in the dynamic oscillatory tests, the frequency sweep (FS) tests were carried out at $8 \%$ of a deformation. The results of the FS tests are presented in Figure 6, where it can be seen that the values of loss modulus (G') were higher than those of the storage modulus ( $\left.\mathrm{G}^{\prime}\right)$ at all concentrations and frequencies tested. These results indicate that the extracted polysaccharide fraction does not lead to gel-like solutions. This behavior can be attributed to the elevated amount of sulfate that was observed in the polysaccharide obtained by papain digestion. The structure of agarans is strongly influenced by the presence of charged groups that participate in intermolecular hydrogen bonds ${ }^{[48]}$; the strength of this polymer gel is inversely proportional to the amount of sulfate present in its structure ${ }^{[64]}$.

The predominantly viscous response reflected in the dynamic and steady state tests suggest that a potential use 


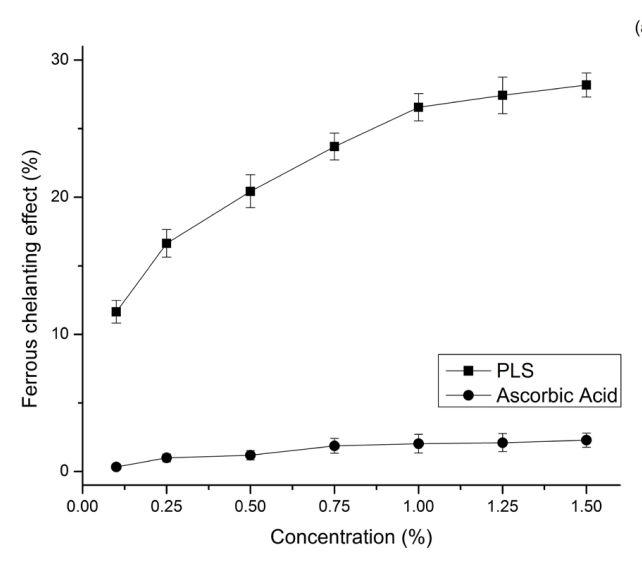

(a)

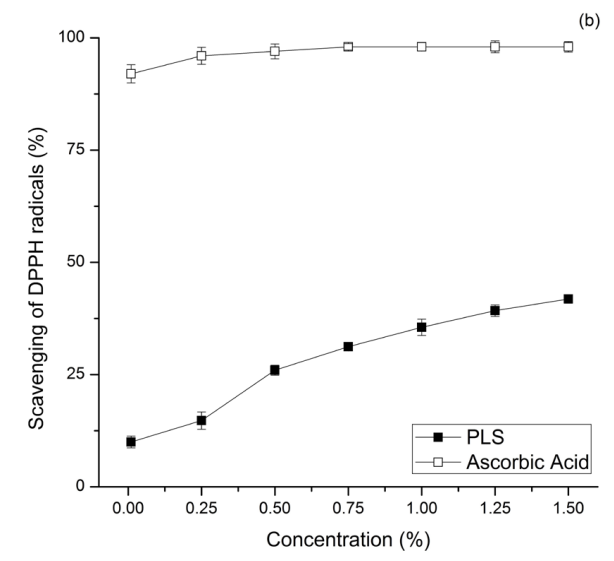

Figure 5. Antioxidant activity of the PLSs extracted from Gracilaria intermedia. (a) Chelating activity of $\mathrm{Fe}^{2+}$ with ascorbic acid used as a positive control. (b) DPPH radical scavenging activity. Values are means $\pm \operatorname{SD}(n=3)$.

for the polysaccharides extracted from the red seaweed Gracilaria intermedia is as a thickening agent, especially for applications where antioxidant activity and absence of color and odor are mandatory requirements. To check this hypothesis, the flow curves at $25 \pm 1^{\circ} \mathrm{C}$ of solutions of the extracted polysaccharides, either pure or in mixture with carboxymethylcellulose (CMC), were compared to those of two solutions containing pure $\mathrm{CMC}$. The concentrations of the pure $\mathrm{CMC}$ solutions were of $0.5 \%$ and $1.5 \%$, corresponding, respectively, to the lower and upper limit of the range of concentrations typically used in commercial applications of $\mathrm{CMC}$ as thickening agent. In the mixtures of $\mathrm{CMC}$ with the extracted polysaccharides, the total concentration of thickening agents was $1.5 \%$. The obtained flow curves are presented in Figure 7.

Figure 7 shows that all the tested solutions presented pseudoplastic behavior, since an increase in shear rate led to a decrease in viscosity. Besides, for all samples, the upward and downward (not shown) curves of shear stress vs. shear rate were identical, with no observed hysteresis behavior. Therefore, the extracted polysaccahride fraction solutions, as well as the two solutions with pure CMC, showed no thixotropy in the range of concentrations tested.

In the case of the extracted polysaccharide fraction solution, the pseudoplastic behavior is likely due to the rupture of the double helix structure present in agaran $\mathrm{s}^{[65]}$. Additionally, the fact that this rupture only occurs above a certain value of tension $\left(t_{\text {crit }}\right)^{[65]}$ is in agreement with the two-region pattern observed in the flow curves, with constant viscosity at low shear rates (Newtonian plateau) and shear-thinning behavior at higher ones. The higher the polysaccharide concentration, the lower the upper limit of the Newtonian plateau because an increase in viscosity causes $t_{\text {crit }}$ be reached at lower values of shear rate.

Additionally, the data corresponding to the shear thinning region of all flow curves presented in Figure 7 were fitted to power-law model. The obtained values of consistency index $(K)$ and power-law index $(n)$ are presented in Table 2. It is observed that increase of the polysaccharide concentration in the PLS solutions led to increase of the consistency index and reduction of the power-law index. Taking into account

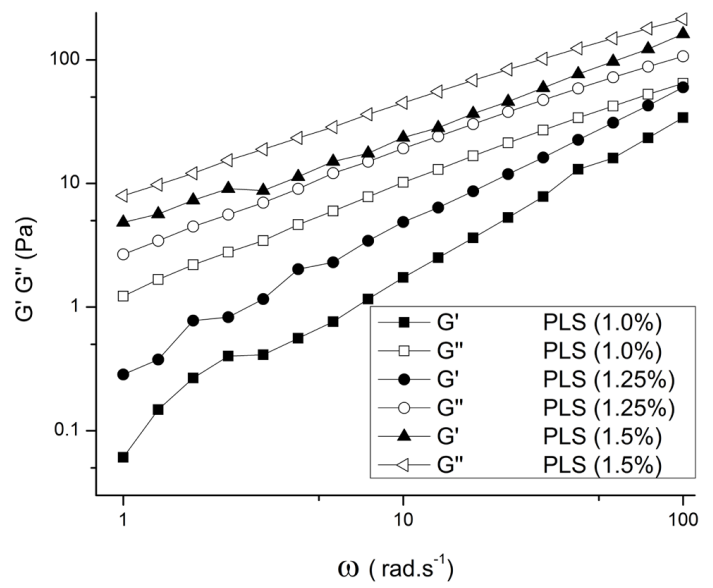

Figure 6. Effect of the concentration of PLS extracted from Gracilaria intermedia on the storage and loss moduli measured during frequency sweeps.

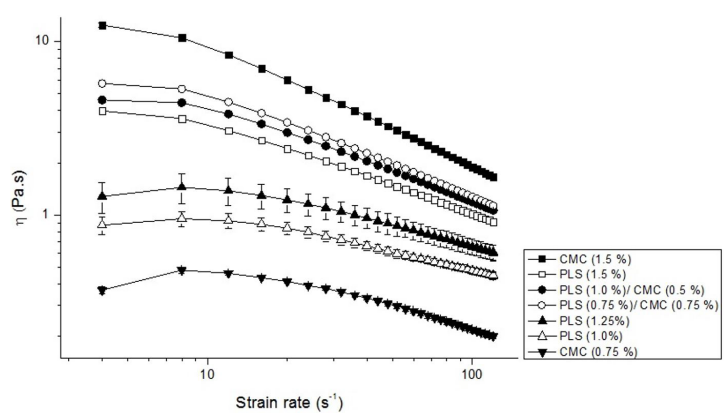

Figure 7. Flow curves of the PLSs extracted from Gracilaria intermedia and of CMC at $25 \pm 1{ }^{\circ} \mathrm{C}$.

that the consistency index is related to the resistance of a fluid to the flow and power-law index indicates how quickly the viscosity is reduced with an increase in the shear rate, the increase of $K$ and reduction of $n$ with the increase of the concentration of PLS in the solution can be explained 
Table 2. Power index $(n)$ and consistency index $(K)$ values for PLS, CMC solutions, and blends of both samples.

\begin{tabular}{lccc}
\hline \multicolumn{1}{c}{ Sample } & Concentration (\%) & $\boldsymbol{n}$ & $\boldsymbol{K}$ (Pa.s) \\
\hline PLS G. intermedia & 1.0 & 0.67 & 2.31 \\
& 1.25 & 0.62 & 5.76 \\
& 1.5 & 0.47 & 11.64 \\
CMC & 0.75 & 0.60 & 1.44 \\
& 1.5 & 0.29 & 47.23 \\
PLS + CMC & 1.0 PLS + 0.5 CMC & 0.43 & 15.83 \\
& 0.75 PLS + 0.75 CMC & 0.39 & 10.11 \\
\hline
\end{tabular}

in terms of the increase in the level of interaction among polysaccharide molecules resulting from the increase in the concentration. As observed in Figure 7, although pure CMC led to the highest viscosity, both pure PLS and the PLS/CMC blends were able to produce a significant increase of viscosity. Actually, all over the range of strain rates studied, pure PLS and the PLS/CMC blends provided viscosity values closer to the that obtained with the $\mathrm{CMC}$ solution of $1.5 \%$ than to those obtained with $0.5 \%$. These results confirm the potential of the extracted sulfated PLS to be used as thickening agent.

\section{Conclusions}

In this study, a water-soluble polysaccharide was successfully extracted from the red seaweed Gracilaria intermedia. The data obtained by spectroscopic methods suggest that the extracted polymeric material is rich in agaran. In vitro studies showed that PLS had antioxidant activity, which may be used for cellular protection against free radicals and to increase the viability of products. The rheological characteristics of PLS indicate that it can be used as a viscosity modifier in industrial processes. The antioxidant characteristics and rheological behavior combined with the organoleptic properties observed (absence of color and odor) make polysaccharides from the seaweed Gracilaria intermedia a promising agent to be used in manufacturing processes of food and pharmaceuticals.

\section{References}

1. Bafana,A. (2013). Characterization and optimization of production of exopolysaccharide from Chlamydomonas reinhardtii. Carbohydrate Polymers, 95(2), 746-752. PMid:23648037. http://dx.doi.org/10.1016/j.carbpol.2013.02.016.

2. Raza, W., Yang, W., Jun, Y., Shakoor, F., Huang, Q., \& Shen, Q. (2012). Optimization and characterization of a polysaccharide produced by Pseudomonas fluorescens WR-1 and its antioxidant activity. Carbohydrate Polymers, 90(2), 921-929. PMid:22840021. http://dx.doi.org/10.1016/j.carbpol.2012.06.021.

3. Sutherland, I. W. (1999). Polysaccharases for microbial exopolysaccharides. Carbohydrate Polymers, 38(4), 319-328. http://dx.doi.org/10.1016/S0144-8617(98)00114-3.

4. Ngah, W. S. W., Teong, L. C., \& Hanafiah, M. A. K. M. (2011). Adsorption of dyes and heavy metal ions by chitosan composites: A review. Carbohydrate Polymers, 83(4), 14461456. http://dx.doi.org/10.1016/j.carbpol.2010.11.004.

5. Jiao, G., Yu, G., Zhang, J., \& Ewart, S. H. (2011). Chemical structures and bioactivities of sulfated polysaccharides from marine algae. Marine Drugs, 9(2), 196-223. PMid:21566795. http://dx.doi.org/10.3390/md9020196.
6. Godard, M., Décordé, K., Ventura, E., Soteras, G., Baccou, J.-C., Cristol, J.-P., \& Rouanet, J.-M. (2009). Polysaccharides from the green alga Ulva rigida improve the antioxidant status and prevent fatty streak lesions in the high cholesterol fed hamster, an animal model of nutritionally-induced atherosclerosis. Food Chemistry, 115(1), 176-180. http://dx.doi.org/10.1016/j. foodchem.2008.11.084.

7. Qi, H., Huang, L., Liu, X., Liu, D., Zhang, Q., \& Liu, S. (2012). Antihyperlipidemic activity of high sulfate content derivative of polysaccharide extracted from Ulva pertusa (Chlorophyta). Carbohydrate Polymers, 87(2), 1637-1640. http://dx.doi. org/10.1016/j.carbpol.2011.09.073.

8. Shao, P., Chen, M., Pei, Y., \& Sun, P. (2013). In intro antioxidant activities of different sulfated polysaccharides from chlorophytan seaweeds Ulva fasciata. International Journal of Biological Macromolecules, 59, 295-300. PMid:23643973. http://dx.doi. org/10.1016/j.ijbiomac.2013.04.048.

9. Souza, B. W. S., Cerqueira, M. A., Martins, J. T., Quintas, M. A. C., Ferreira, A. C. S., Teixeira, J. A., \& Vicente, A. A. (2011). Antioxidant potential of two red seaweeds from the brazilian coasts. Journal of Agricultural and Food Chemistry, 59(10), 5589-5594. PMid:21491929. http://dx.doi.org/10.1021/ jf200999n.

10. Domenek, S., Louaifi, A., Guinault, A., \& Baumberger, S. (2013). Potential of Lignins as Antioxidant Additive in Active Biodegradable Packaging Materials. Journal of Polymers and the Environment, 21(3), 692-701. http://dx.doi.org/10.1007/ s10924-013-0570-6.

11. Schreiber, S. B., Bozell, J. J., Hayes, D. G., \& Zivanovic, S. (2013). Introduction of primary antioxidant activity to chitosan for application as a multifunctional food packaging material. Food Hydrocolloids, 33(2), 207-214. http://dx.doi. org/10.1016/j.foodhyd.2013.03.006.

12. Souza, B. W. S., Cerqueira, M. A., Bourbon, A. I., Pinheiro, A. C., Martins, J. T., Teixeira, J. A., Coimbra, M. A., \& Vicente, A. A. (2012). Chemical characterization and antioxidant activity of sulfated polysaccharide from the red seaweed Gracilaria birdiae. Food Hydrocolloids, 27(2), 287-292. http://dx.doi. org/10.1016/j.foodhyd.2011.10.005.

13. Cheng, H., Feng, S., Shen, S., Zhang, L., Yang, R., Zhou, Y., \& Ding, C. (2013). Extraction, antioxidant and antimicrobial activities of Epimedium acuminatum Franch. polysaccharide. Carbohydrate Polymers, 96(1), 101-108. PMid:23688459. http://dx.doi.org/10.1016/j.carbpol.2013.03.072.

14. Dore, C. M. P. G., Alves, M. G. C. F., Will, L. S. E. P., Costa, T. G., Sabry, D. A., Rêgo, L. A. R. S., Accardo, C. M., Rocha, H. A. O., Filgueira, L. G. A., \& Leite, E. L. (2013). A sulfated polysaccharide, fucans, isolated from brown algae Sargassum vulgare with anticoagulant, antithrombotic, antioxidant and anti-inflammatory effects. Carbohydrate Polymers, 91(1), 467-475. PMid:23044157. http://dx.doi.org/10.1016/j. carbpol.2012.07.075.

15. Liu, X., Sun, Z., Zhang, M., Meng, X., Xia, X., Yuan, W., Xue, F., \& Liu, C. (2012). Antioxidant and antihyperlipidemic activities of polysaccharides from sea cucumber Apostichopus japonicus. Carbohydrate Polymers, 90(4), 1664-1670. PMid:22944431. http://dx.doi.org/10.1016/j.carbpol.2012.07.047.

16. Wu, M., Wu, Y., Qu, M., Li, W., \& Yan, X. (2013). Evaluation of antioxidant activities of water-soluble polysaccharides from brown alga Hizikia fusiformis. International Journal of Biological Macromolecules, 56, 28-33. PMid:23396065. http://dx.doi.org/10.1016/j.ijbiomac.2013.01.017.

17. Yang, X., Yang, S., Guo, Y., Jiao, Y., \& Zhao, Y. (2013). Compositional characterisation of soluble apple polysaccharides, and their antioxidant and hepatoprotective effects on acute CCl4-caused liver damage in mice. Food Chemistry, 138(2-3), 
1256-1264. PMid:23411241. http://dx.doi.org/10.1016/j. foodchem.2012.10.030.

18. Zhang, Z., Wang, F., Wang, M., Ma, L., \& Zeng, X. (2012). Extraction optimisation and antioxidant activities in vitro of polysaccharides from Allium macrostemon Bunge. International Journal of Food Science \& Technology, 47(4), 723-730. http:// dx.doi.org/10.1111/j.1365-2621.2011.02899.x.

19. Kumar, K. S., Ganesan, K., \& Rao, P. V. S. (2008). Antioxidant potential of solvent extracts of Kappaphycus alvarezii (Doty) Doty - An edible seaweed. Food Chemistry, 107(1), 289-295. http://dx.doi.org/10.1016/j.foodchem.2007.08.016.

20. Martín, L. A., Rodríguez, M. C., Matulewicz, M. C., Fissore, E. N., Gerschenson, L. N., \& Leonardi, P. I. (2013). Seasonal variation in agar composition and properties from Gracilaria gracilis (Gracilariales, Rhodophyta) of the Patagonian coast of Argentina. Phycological Research, 61(3), 163-171. http:// dx.doi.org/10.1111/pre.12000.

21. Niu, J., Xu, M., Wang, G., Zhang, K., \& Peng, G. (2013). Comprehensive Extraction of Agar and R-Phycoerythrin from Gracilaria lemaneiformis (Bangiales, Rhodophyta). Indian Journal Geo-Marine Science, 42, 21-28.

22. Rodríguez-Montesinos, Y. E., Arvizu-Higuera, D. L., Hernández-Carmona, G., Muñoz-Ochoa, M., \& MurilloÁlvarez, J. I. (2013). Seasonal variation of the agar quality and chemical composition of Gracilaria veleroae and Gracilaria vermiculophylla (Rhodophyceae, Gracilariaceae) from Baja California Sur, Mexico. Phycological Research, 61(2), 116123. http://dx.doi.org/10.1111/pre.12008.

23. Maciel, J. S., Chaves, L. S., Souza, B. W. S., Teixeira, D. I. A., Freitas, A. L. P., Feitosa, J. P. A., \& Paula, R. C. M. (2008). Structural characterization of cold extracted fraction of soluble sulfated polysaccharide from red seaweed Gracilaria birdiae. Carbohydrate Polymers, 71(4), 559-565. http://dx.doi. org/10.1016/j.carbpol.2007.06.026.

24. Lahaye, M., \& Yaphe, W. (1988). Effects of seasons on the chemical structure and gel strength of Gracilaria pseudoverrucosa agar (Gracilariaceae, rhodophyta). Carbohydrate Polymers, 8(4), 285-301. http://dx.doi.org/10.1016/0144-8617(88)90067-7.

25. Araki, C. (1966). Some recent studies on the polysaccharides of agarophytes. In Proceedings of the Fifth International Seaweed Symposium (pp. 3-17). Halifax, Canada: Pergamon Press.

26. Barros, F. C. N., Silva, D. C., Sombra, V. G., Maciel, J. S., Feitosa, J. P. A., Freitas, A. L. P., \& Paula, R. C. M. (2013). Structural characterization of polysaccharide obtained from red seaweed Gracilaria caudata (J Agardh). Carbohydrate Polymers, 92(1), 598-603. PMid:23218341. http://dx.doi. org/10.1016/j.carbpol.2012.09.009.

27. Vidotti, E. C., \& Rollemberg, M. C. E. (2004). Algas: da economia nos ambientes aquáticos à bioremediação e à química analítica. Quimica Nova, 27(1), 139-145. http://dx.doi. org/10.1590/S0100-40422004000100024.

28. Coura, C. O., Araújo, I. W. F., Vanderlei, E. S. O., Rodrigues, J. A. G., Quinderé, A. L. G., Fontes, B. P., Queiroz, I. N. L., Menezes, D. B., Bezerra, M. M., Silva, A. A. R., Chaves, H. V., Jorge, R. J. B., Evangelista, J. S. A. M., \& Benevides, N. M. B. (2012). Antinociceptive and anti-inflammatory activities of sulphated polysaccharides from the Red Seaweed Gracilaria cornea. Basic \& Clinical Pharmacology \& Toxicology, 110(4), 335-341. PMid:21985563. http://dx.doi.org/10.1111/j.17427843.2011.00811.x.

29. Solé, M., \& Barrios, J. (2009). Catálogo de las macroalgas marinas del golfo de Paria y delta del Orinoco, Venezuela. Memoria de la Fundación La Salle de Ciencias Naturales, 171, 99-112.

30. Kim, M.-S., Yang, E. C., \& Boo, S. M. (2006). Taxonomy and phylogeny of flattened species of Gracilaria (Gracilariceae,
Rhodophyta) from Korea based on morphology and proteincoding plastid rbcL and psbA sequences. Phycologia, 45(5), 520-528. http://dx.doi.org/10.2216/05-38.1.

31. Gurgel, C. F. D., Fredericq, S., Norris, J. N., \& YoneshigueValentin, Y. (2008). Two New Flat Species of Gracilaria (Gracilariales, Rhodophyta) From Brazil: G. Abyssalis sp. nov. and G. Brasiliensis sp. nov. Phycologia, 47(3), 249-264. http://dx.doi.org/10.2216/PH06-59.1.

32. Lyra, M. G., Nunes, J. M. C., Jesus, P. B., Lázaro, J. L., \& Assis, J. G. A. (2011). Aspectos ecológicos de Gracilaria Grev. (Gracilariales, Rhodophyta) em uma praia tropical brasileira. Revista Gestão Costeira Integrada, 11(4), 451-457. http:// dx.doi.org/10.5894/rgci273.

33. Farias, W. R., Valente, A. P., Pereira, M. S., \& Mourão, P. A. (2000). Structure and Anticoagulant Activity of Sulfated Galactans Isolation of a unique sulfated galactan from the red algae Botryocladia occidentalis and comparison of its anticoagulant action with that of sulfated galactans from invertebrates. The Journal of Biological Chemistry, 275(38), 29299-29307. PMid:10882718. http://dx.doi.org/10.1074/jbc. M002422200.

34. Dodgson, K. S., \& Price, R. G. (1962). A note on the determination of the ester sulphate content of sulphated polysaccharides. The Biochemical Journal, 84(1), 106-110. PMid:13886865. http:// dx.doi.org/10.1042/bj0840106.

35. DuBois, M., Gilles, K. A., Hamilton, J. K., Rebers, P. A., \& Smith, F. (1956). Colorimetric method for determination of sugars and related substances. Analytical Chemistry, 28(3), 350-356. http://dx.doi.org/10.1021/ac60111a017.

36. Bradford, M. M. (1976). A rapid and sensitive method for the quantitation of microgram quantities of protein utilizing the principle of protein-dye binding. Analytical Biochemistry, 72(1), 248-254. PMid:942051. http://dx.doi.org/10.1016/00032697(76)90527-3.

37. Kircher, H. W. (1960). Gas-liquid partition chromatography of methylated sugars. Analytical Chemistry, 32(9), 1103-1106. http://dx.doi.org/10.1021/ac60165a016.

38. Lahaye, M., Yaphe, W., Viet, M. T. P., \& Rochas, C. (1989). ${ }^{13} \mathrm{C}$-n.m.r. spectroscopic investigation of methylated and charged agarose oligosaccharides and polysaccharides. Carbohydrate Research, 190(2), 249-265. http://dx.doi.org/10.1016/00086215(89)84129-1.

39. Miller, I. J., \& Furneaux, R. H. (1997). The Structural Determination of the Agaroid Polysaccharides from Four New Zealand Algae in the Order Ceramiales by Means of ${ }^{13}$ CNMR Spectroscopy. Botanica Marina, 40(1-6), 333-340. http://dx.doi.org/10.1515/botm.1997.40.1-6.333.

40. Usov, A. I., Yarotsky, S. V., \& Shashkov, A. S. (1980). ${ }^{13}$ C-nmr spectroscopy of red algal galactans. Biopolymers, 19(5), 977990. http://dx.doi.org/10.1002/bip.1980.360190504.

41. Valiente, O., Fernandez, L. E., Perez, R. M., Marquina, G., \& Velez, H. (1992). Agar Polysaccharides from the Red Seaweeds Gracilaria domingensis Sonder ex Kützing and Gracilaria mammillaris (Montagne) Howe. Botanica Marina, 35(2), 77-82. http://dx.doi.org/10.1515/botm.1992.35.2.77.

42. Prieto, P., Pineda, M., \& Aguilar, M. (1999). Spectrophotometric Quantitation of Antioxidant Capacity through the Formation of a Phosphomolybdenum Complex: Specific Application to the Determination of Vitamin E. Analytical Biochemistry, 269(2), 337-341. PMid:10222007. http://dx.doi.org/10.1006/ abio.1999.4019.

43. Chun-hui, L., Chang-hai, W., Zhi-liang, X., \& Yi, W. (2007). Isolation, chemical characterization and antioxidant activities of two polysaccharides from the gel and the skin of Aloe barbadensis Miller irrigated with sea water. Process Biochemistry, 42(6), 961-970. http://dx.doi.org/10.1016/j.procbio.2007.03.004. 
44. Qi, H., Zhang, Q., Zhao, T., Chen, R., Zhang, H., Niu, X., \& Li, Z. (2005). Antioxidant activity of different sulfate content derivatives of polysaccharide extracted from Ulva pertusa (Chlorophyta) in vitro. International Journal of Biological Macromolecules, 37(4), 195-199. PMid:16310843. http:// dx.doi.org/10.1016/j.ijbiomac.2005.10.008.

45. Zhang, Z., Wang, X., Zhang, J., \& Zhao, M. (2011). Potential antioxidant activities in vitro of polysaccharides extracted from ginger (Zingiber officinale). Carbohydrate Polymers, 86(2), 448-452. http://dx.doi.org/10.1016/j.carbpol.2011.04.062.

46. Murugan, K., \& Iyer, V. V. (2013). Differential growth inhibition of cancer cell lines and antioxidant activity of extracts of red, brown, and green marine algae. In Vitro Cellular \& Developmental Biology. Animal, 49(5), 324-334. PMid:23645467. http://dx.doi. org/10.1007/s11626-013-9603-7.

47. Melo, M. R. S., Feitosa, J. P. A., Freitas, A. L. P., \& Paula, R. C. M. (2002). Isolation and characterization of soluble sulfated polysaccharide from the red seaweed Gracilaria cornea. Carbohydrate Polymers, 49(4), 491-498. http://dx.doi. org/10.1016/S0144-8617(02)00006-1.

48. Freile-Pelegrín, Y., \& Robledo, D. (1997). Influence of alkali treatment on agar from Gracilaria cornea from Yucatán, México. Journal of Applied Phycology, 9(6), 533-539. http://dx.doi. org/10.1023/A:1007989931915.

49. Mehta, G. K., Meena, R., Prasad, K., Ganesan, M., \& Siddhanta, A. K. (2010). Preparation of galactans from Gracilaria debilis and Gracilaria salicornia (Gracilariales, Rhodophyta) of Indian waters. Journal of Applied Phycology, 22(5), 623-627. http:// dx.doi.org/10.1007/s10811-010-9502-1.

50. Amorim, R. N. S., Rodrigues, J. A. G., Holanda, M. L., Quinderé, A. L. G., Paula, R. C. M., Melo, V. M. M., \& Benevides, N. M. B. (2012). Antimicrobial effect of a crude sulfated polysaccharide from the red seaweed Gracilaria ornata. Brazilian Archives of Biology and Technology, 55(2), 171-181. http://dx.doi.org/10.1590/S1516-89132012000200001.

51. Vanderlei, E. S. O., Araújo, I. W. F., Quinderé, A. L. G., Fontes, B. P., Eloy, Y. R. G., Rodrigues, J. A. G., Silva, A. A. R., Chaves, H. V., Jorge, R. J. B., Menezes, D. B., Evangelista, J. S. A. M., Bezerra, M. M., \& Benevides, N. M. B. (2011). The involvement of the HO-1 pathway in the anti-inflammatory action of a sulfated polysaccharide isolated from the red seaweed Gracilaria birdiae. Inflammation Research, 60(12), 1121-1130. PMid:21879365. http://dx.doi.org/10.1007/s00011011-0376-8.

52. Pomin, V. H., \& Mourão, P. A. (2008). Structure, biology, evolution, and medical importance of sulfated fucans and galactans. Glycobiology, 18(12), 1016-1027. PMid:18796647. http://dx.doi.org/10.1093/glycob/cwn085.

53. Prado-Fernández, J., Rodríguez-Vázquez, J. A., Tojo, E., \& Andrade, J. M. (2003). Quantitation of $\kappa-, ~ l-$ and $\lambda$-carrageenans by mid-infrared spectroscopy and PLS regression. Analytica Chimica Acta, 480(1), 23-37. http://dx.doi.org/10.1016/S00032670(02)01592-1.

54. Rochas, C., Lahaye, M., \& Yaphe, W. (1986). Sulfate Content of Carrageenan and Agar Determined by Infrared Spectroscopy. Botanica Marina, 29(4), 335-340. http://dx.doi.org/10.1515/ botm.1986.29.4.335.

55. Mollet, J.-C., Rahaoui, A., \& Lemoine, Y. (1998). Yield, chemical composition and gel strength of agarocolloids of Gracilaria gracilis, Gracilariopsis longissima and the newly reported Gracilaria cf. vermiculophylla from Roscoff (Brittany,
France). Journal of Applied Phycology, 10(1), 59-66. http:// dx.doi.org/10.1023/A:1008051528443.

56. Chopin, T., \& Whalen, E. (1993). A new and rapid method for carrageenan identification by FT IR diffuse reflectance spectroscopy directly on dried, ground algal material. Carbohydrate Research, 246(1), 51-59. http://dx.doi.org/10.1016/00086215(93)84023-Y.

57. Parekh, R. G., Doshi, Y. A., Rao, V. D., \& Chauhan, V. D. (1987). Studies on a phycocolloid from red alga Halymenia venusta Boergesen. Indian Journal of Geo-Marine Sciences, 16, 274-276.

58. Batista, J. A., Dias, E. G. N., Brito, T. V., Prudêncio, R. S., Silva, R. O., Ribeiro, R. A., Souza, M. H., Paula, R. C., Feitosa, J. P., Chaves, L. S., Melo, M. R., Freitas, A. L., Medeiros, J. V., \& Barbosa, A. L. (2014). Polysaccharide isolated from Agardhiella ramosissima: Chemical structure and anti-inflammation activity. Carbohydrate Polymers, 99(1), 59-67. PMid:24274479. http:// dx.doi.org/10.1016/j.carbpol.2013.08.071.

59. Mazumder, S., Ghosal, P. K., Pujol, C. A., Carlucci, M. J., Damonte, E. B., \& Ray, B. (2002). Isolation, chemical investigation and antiviral activity of polysaccharides from Gracilaria corticata (Gracilariaceae, Rhodophyta). International Journal of Biological Macromolecules, 31(1-3), 87-95. PMid:12559431. http://dx.doi.org/10.1016/S0141-8130(02)00070-3.

60. Wang, L., Yao, Y., Sang, W., Yang, X., \& Ren, G. (2015). Structural features and immunostimulating effects of three acidic polysaccharides isolated from Panax quinquefolius. International Journal of Biological Macromolecules, 80, 77-86. PMid:26056990. http://dx.doi.org/10.1016/j.ijbiomac.2015.06.007.

61. Xia, Y.-G., Liang, J., Yang, B.-Y., Wang, Q.-H., \& Kuang, H.-X. (2015). Structural studies of an arabinan from the stems of Ephedra sinica by methylation analysis and 1D and 2D NMR spectroscopy. Carbohydrate Polymers, 121, 449-456. PMid:25659720. http://dx.doi.org/10.1016/j.carbpol.2014.12.058.

62. Costa, L. S., Fidelis, G. P., Cordeiro, S. L., Oliveira, R. M., Sabry, D. A., Câmara, R. B. G., Nobre, L. T. D. B., Costa, M. S. S. P., Almeida-Lima, J., Farias, E. H. C., Leite, E. L., \& Rocha, H. A. O. (2010). Biological activities of sulfated polysaccharides from tropical seaweeds. Biomedicine and Pharmacotherapy, 64(1), 21-28. PMid:19766438. http://dx.doi. org/10.1016/j.biopha.2009.03.005.

63. Wang, J., Zhang, Q., Zhang, Z., \& Li, Z. (2008). Antioxidant activity of sulfated polysaccharide fractions extracted from Laminaria japonica. International Journal of Biological Macromolecules, 42(2), 127-132. PMid:18023861. http:// dx.doi.org/10.1016/j.ijbiomac.2007.10.003.

64. Cosson, J., Deslandes, E., Zinoun, M., \& Mouradi-Givernaud, A. (1995). Carrageenans and agars, red algal polysaccharides. In: F. E. Round \& D. J. Chapman (Eds.), Progress in phycological research (pp. 269-324). Bristol: Biopress Ltd.

65. Grant, C. A., Twigg, P. C., Savage, M. D., Woon, W. H., \& Greig, D. (2012). Mechanical investigations on agar gels using atomic force microscopy: effect of deuteration. Macromolecular Materials and Engineering, 297(3), 214-218. http://dx.doi. org/10.1002/mame.201100164.

Received: Oct. 11, 2016

Revised: Apr. 13, 2017 Accepted: June 17, 2017 